19 Revue d'histoire du XIXe siècle

Société d'histoire de la révolution de 1848 et des

révolutions du XIXe siècle

2 | 1986

Varia

\title{
La compagnie de sapeurs-pompiers. Une association volontaire en milieu populaire au XIXe siècle
}

Hubert Lussier

\section{OpenEdition}

\section{Journals}

Electronic version

URL: http://journals.openedition.org/rh19/10

DOI: $10.4000 /$ rh 19.10

ISSN: $1777-5329$

Publisher

La Société de 1848

Printed version

Date of publication: 1 June 1986

ISSN: 1265-1354

\section{Electronic reference}

Hubert Lussier, «La compagnie de sapeurs-pompiers. Une association volontaire en milieu populaire au XIXe siècle », Revue d'histoire du XIXe siècle [Online], 2 | 1986, Online since 03 September 2008, connection on 19 April 2019. URL : http://journals.openedition.org/rh19/10 ; DOI : 10.4000/rh19.10

This text was automatically generated on 19 April 2019

Tous droits réservés 


\section{La compagnie de sapeurs-pompiers. Une association volontaire en milieu populaire au XIXe siècle}

Hubert Lussier

\section{ABSTRACTS}

No abstract available by now

Pas de résumé disponible actuellement

INDEX

Mots-clés: Pompiers 